\title{
Pengaruh Model Pembelajaran Inkuiri Terhadap Perubahan Pengetahuan dan Sikap Siswa Tentang Bahaya Merokok di SMAN 1 Kotamobagu
}

\author{
Hamzah B \\ Prodi S1 Kesehatan Masyarakat STIKES Graha Medika, Jl. Raya AKD RSI Moonow \\ Lantai II, Mongkonai Barat, Kotamobagu \\ e-mail: hamzahbskm@gmail.com
}

\begin{abstract}
Abstrak
Perilaku merokok sudah mulai banyak dilakukan oleh usia remaja (10-18 tahun). Prevalensi merokok pada remaja di Indonesia sebesar 9,1\%. Di Sulawesi Utara prevalensi merokok sebesar $29,64 \%$, angka ini masih diatas rata-rata nasional. Untuk menekan angka prevalensi merokok yang cukup tinggi diperlukan penyuluhan kesehatan yang lebih efektif tentang bahaya merokok pada usia sekolah. Tujuan penelitian ini adalah untuk mengetahui pengaruh model pembelajaran inkuiri terhadap perubahan pengetahuan dan sikap siswa tentang bahaya merokok di SMAN 1 Kotamobagu. Penelitian ini merupakan penelitian pre-experimental design dengan rancangan penelitian one group pretest-post test design. Jumlah sampel yang digunakan sebanyak 30 responden yang ditarik menggunakan simple random sampling. Data dikumpulkan menggunakan kuesioner dan dianalisis dengan uji paired t-test. Hasil penelitian menunjukkan ada pengaruh model pembelajaran inkuiri terhadap peningkatan pengatahuan dan sikap siswa tentang bahaya merokok di SMAN 1 Kotamobagu, diperoleh nilai $p=0,000$ ( $p$ $<0,05$ ) dengan perbedaan rata-rata skor (mean) pengetahuan responden pada saat pre-test dan post-test sebesar 9,88 dan perbedaan rata-rata skor (mean) sikap responden pada saat pre-test dan post-test sebesar 32,31. Disarankan kepada dinas kesehatan Kotamobagu untuk mengembangkan penyuluhan dan memberikan pelatihan kepada petugas kesehatan tentang model pembelajaran inkuiri.
\end{abstract}

Kata kunci: Pembelajaran Inkuiri, Merokok, Pengetahuan, Sikap

\section{The Effect of Inquiry Learning Model on Changes in Knowledge and Attitudes of Students About the Dangers of Smoking at SMAN 1 Kotamobagu}

\begin{abstract}
Smoking behavior has started to be done by adolescents (10-18 years). The prevalence of smoking among adolescents in Indonesia is $9.1 \%$. In North Sulawesi, the prevalence of smoking is $29.64 \%$, this figure is still above the national average. To reduce the high prevalence of smoking, a more effective health education is needed about the dangers of smoking at school age. The purpose of this study was to determine the effect of the inquiry learning model on changes in students' knowledge and attitudes about the dangers of smoking in SMAN 1 Kotamobagu. This research is a pre-experimental research design with one group pretest-post test design. The number of samples used was 30 respondents who were drawn using simple random sampling. Data were collected using a questionnaire and analyzed using paired t-test. The results showed that there was an effect of the inquiry learning model on increasing students knowledge and attitudes about the dangers of smoking in SMAN 1 Kotamobagu, obtained a value of $p=0,000(p<0,05)$ with a difference in the mean score (mean) of respondents' knowledge at the time of the pre-test. and post-test 9,88 and the difference in the mean score (mean) of respondents' attitudes at the pre-test and post-test was 32,31 . It is recommended that the Kotamobagu health office develop counseling and provide training to health workers on inquiry learning models.
\end{abstract}


Keywords: Inquiry Learning, Smoking, Knowledge, Attitude

\section{Pendahuluan}

Menurut The Tobacco Atlas 3rd edition terkait persentase penduduk dunia yang mengkomsi tembakau didapatkan sebanyak $57 \%$ pada Asia dan Australia, $14 \%$ pada penduduk Eropa Timur dan pecahan Uni Soviet, 12\% penduduk Amerika, 9\% penduduk Eropa Barat, dan 8\% pada penduduk Timur Tengah serta Afrika. Sementara itu ASEAN merupakan sebuah kawasan dengan $10 \%$ dari seluruh perokok dunia dan $20 \%$ penyebab kematian global akibat tembakau. Persentase perokok pada penduduk di negara ASEAN tersebar di Indonesia (46,16\%), Filipina $(16,62 \%)$, Vietnam $(14,11 \%)$, Myanmar (8,73\%), Thailand $(7,74 \%)$, Malaysia $(2,90 \%)$, Kamboja $(2,07)$, Laos (1,23\%), Singapura (0,39\%), dan Brunei (0,04\%) (Kemenkes RI, 2014).

Data World Health Organization (WHO) didapatkan setiap 6 detik terdapat satu kematian disebabkan tembakau di seluruh dunia. Pada tahun 2005, sebanyak 5,4 juta jiwa meninggal karena tembakau dan selama abad ke 20 kematian akibat tembakau sebanyak 100 juta. Jika hal ini dibiarkan maka pada tahun 2030 akan terjadi 8 juta kematian dan diperkirakan selama abad ke 21 akan terjadi kematian sebanyak 1 milyar jiwa akibat tembakau (Hutapea et al., 2017).

Prevalensi merokok pada populasi usia 10-18 tahun berdasarkan hasil Riset Kesehatan Dasar tahun 2018 yakni sebesar 9,1\%. Sulawesi Utara sendiri memiliki tingkat prevalensi sebesar $29,64 \%$ yang masih berada diatas rata-rata Nasional. Target Rencana Pembagunan Jangka Menengah Nasional tahun 2019 untuk prevalensi penduduk yang merokok usia $\leq 18$ tahun yakni sebesar $5,4 \%$ (Kemenkes RI, 2018).

Usia anak sekolah 12-18 tahun adalah periode masa penemuan diri dan kepekaan rasa sosial. Pada masa ini kepribadian harus dikembangkan sepenuhnya dan harus sadar akan keharusankeharusan. Kenyataan adanya siswa SMA yang merokok tentu membuat keprihatinan, siswa SMA merupakan anak-anak bangsa yang diharapkan kelak menjadi generasi penerus. Jika sejak dini remaja sudah diracuni oleh rokok, maka hal ini akan berpengaruh tidak hanya pada keadaan fisik tetapi juga mental (Martias \& Nursamsi, 2017).

Hasil studi pendahuluan di SMAN 1 Kotamobagu dari 58 siswa laki-laki SMAN 1 Kotamobagu sebanyak 42 siswa yang menyatakan pernah merokok dan 16 yang tidak merokok. Dari 42 siswa yang pernah merokok hanya $21 \%$ yang mengetahui secara jelas tentang bahaya merokok bagi diri sendiri dan lingkungannya. Hasil wawancara didapatkan alasan siswa merokok adalah coba-coba dan ikut-ikutan dari teman. Menurut (Nugroho, 2017) perokok pemula akan merasakan batuk, lidah terasa mual, dan perut mual, namun akan berlanjut menjadi kebiasaan dan akhirnya menjadi ketergantungan. ketergantungan ini dipersepsikan sebagai kenikmatan yang memberikan kepuasaan psikologis. Sehingga tidak jarang perokok mendapatkan kenikmatan yang dapat menghilangkan ketidaknyamanan yang sedang dialaminya dan perokok tidak sadar bahwa penyakit sedang mengintai.

Kurangnya kesadaran dan sikap negatif masyarakat tentang bahaya merokok bagi diri dan orang-orang di sekelilingnya menyebabkan kurangnya kemampuan masyarakat untuk merubah perilakunya dan menciptakan lingkungan yang sehat. Untuk itu perlu dilakukan upaya pencegahan baik di lingkungan rumah, sekolah, maupun lingkungan masyarakat. Salah satu upaya pencegahan yang dapat dilakukan adalah kegiatan penyuluhan dan bimbingan untuk memberikan penerangan dan pengetahuan kepada sasaran yang menyalahgunakan dan untuk membangkitkan kesadaran mereka tentang rokok (Rusmilawaty, 2016).

Berdasarkan latar belakang di atas, maka peneliti tertarik melakukan penelitian mengenai pengaruh model pembelajaran inkuiri terhadap perubahan pengetahuan dan sikap siswa tentang bahaya merokok di SMA Negeri 1 Kotamobagu.

Pharmed Vol. 3, No. 2, Agustus 2020: 55 - 61 


\section{Metode Penelitian}

Penelitian ini menggunakan jenis penelitian pre-experimental design dengan rancangan penelitian one group pretest-post test design. Penelitian ini dilaksanakan pada bulan Januari 2020 dengan subjek penelitian adalah 30 siswa kelas $X$ dan XI SMAN 1 Kotamobagu yang memenuhi kriteria inklusi (perokok aktif, dan belum pernah mengikuti penyuluhan tentang rokok) dan kriteria eksklusi (responden yang buta huruf dan dalam keadaan sakit). Sampel ditarik menggunakan teknik simple random sampling. Data di kumpulkan menggunakan kuesioner yang diberikan kepada responden sebagai pre-test kemudian responden diberikan penyuluhan kesehatan tentang bahaya merokok dengan model pembelajaran inkuiri setelah dua minggu responden kembali diberikan kuesioner sebagai post-test. Analisis data menggunakan uji paired t-test.

\section{Hasil dan Pembahasan}

\section{Deskripsi Variabel Penelitian}

Penelitian ini terdiri atas variabel terikat yaitu penyuluhan kesehatan dengan model pembelajaran inkuiri tentang bahaya merokok. Penyuluhan dengan model pembelajaran inkuiri adalah merupakan kegiatan pembelajaran yang melibatkan secara maksimal seluruh kemampuan siswa untuk mencari dan menyelidiki tentang bahaya merokok secara sistematis, kritis, logis, analitis kemudian mengungkapkan hasil temuannya dengan penuh percaya diri. Sedangkan variabel bebas terdiri atas pengetahuan dan sikap siswa SMAN 1 Kotamobagu.

Tabel 1. Karakteristik Responden Berdasarkan Skor Pengetahuan dan Sikap tentang Bahaya Merokok Saat Pre-test dan Post-test di SMAN 1 Kotamobagu Tahun 2020

\begin{tabular}{lcccc} 
& Skor min. & Skor max. & Mean & SD \\
\hline Pengetahuan & 7 & 13 & 10,15 & 1,724 \\
Pre-test & 18 & 22 & 20,03 & 1,783 \\
Post-test & & & & \\
Sikap & 23 & 60 & 35,17 & 9,401 \\
Pre-test & 44 & 75 & 67,48 & 11,638 \\
Post-test & & & & \\
\hline
\end{tabular}

Tabel 1 di atas menunjukkan bahwa rata-rata (mean) pengetahuan responden tentang bahaya merokok pada saat pre-test adalah 10,15 dengan standar deviasi 1,724 dan pada post-test meningkat menjadi 20,03 dengan standar deviasi 1,783. Skor pengetahuan terendah pada saat pre-test adalah 7 dan skor tertinggi adalah 13 dan pada saat post-test skor pengetahuan terendah pada adalah 18 dan skor tertinggi adalah 22. Selanjutnya rata-rata (mean) sikap responden tentang bahaya merokok pada saat pre-test adalah 35,17 dengan standar deviasi 9,401 dan pada post-test meningkat menjadi 67,48 dengan standar deviasi 11,638. Skor sikap terendah pada saat pre-test adalah 23 dan skor tertinggi adalah 60 dan pada saat post-test skor sikap terendah pada adalah 44 dan skor tertinggi adalah 75 .

\section{Pengaruh Model Pembelajaran Inkuiri Terhadap Perubahan Pengetahuan dan Sikap Siswa tentang Bahaya Merokok di SMAN 1 Kotamobagu}

Dalam penelitian ini analisis bivariat dilakukan untuk mengetahui adanya pengaruh model pembelajaran inkuiri terhadap perubahan pengetahuan dan siswa tentang bahaya merokok. 
Tabel 2. Pengaruh Model Pembelajaran Inkuiri Terhadap Perubahan Pengetahuan Siswa tentang Merokok Pada Saat Pre-test dan Post-test di SMAN 1 Kotamobagu

\begin{tabular}{lccccc}
\hline Pengetahuan & $\mathbf{n}$ & Mean & SD & SE & p value \\
\hline Pre-test & 30 & 10,15 & 1,724 & 0,362 & $\mathrm{p}=0,000$ \\
Post-test & 30 & 20,03 & 1,783 & 0,382 & \\
\hline
\end{tabular}

Tabel 2 menunjukkan bahwa terjadi peningkatan rata-rata skor (mean) pengetahuan responden tentang bahaya merokok pada saat pre-test ke post-test setelah diberikan model pembelajaran inkuiri. Terjadi peningkatan rata-rata skor (mean) pengetahuan responden tentang bahaya merokok setelah diberikan model pembelajaran inkuiri pada saat pre-test ke post-test. Hasil uji statistik diperoleh nilai $p=$ $0,000(p<0,05)$ menunjukkan bahwa ada perbedaan rata-rata skor (mean) pengetahuan responden pada saat pre-test dan post-test sebesar 9,88 sehingga dapat disimpulkan bahwa ada pengaruh model pembelajaran inkuiri terhadap perubahan pengetahuan siswa tentang bahaya merokok.

Tabel 3. Pengaruh Model Pembelajaran Inkuiri Terhadap Perubahan sikap Siswa tentang Merokok Pada Saat Pre-test dan Post-test di SMAN 1 Kotamobagu

\begin{tabular}{l|c|c|c|c|c}
\hline \multicolumn{1}{c|}{ Sikap } & $\mathbf{n}$ & Mean & SD & SE & $\boldsymbol{p}$ value \\
\hline Pre-test & 30 & 35,17 & 9,401 & 1,819 & $\mathrm{p}=0,000$ \\
Post-test & 30 & 67,48 & 11,638 & 1,179 & \\
\hline
\end{tabular}

Tabel 3 menunjukkan bahwa terjadi peningkatan rata-rata skor (mean) sikap responden tentang bahaya merokok pada saat pre-test ke post-test setelah diberikan model pembelajaran inkuiri. Terjadi peningkatan rata-rata skor (mean) sikap responden tentang bahaya merokok setelah diberikan model pembelajaran inkuiri pada saat pretest ke post-test. Hasil uji statistik diperoleh nilai $p=0,000(p<0,05)$ menunjukkan bahwa ada perbedaan yang signifikan rata-rata skor (mean) sikap responden pada saat pre-test dan post-test sebesar 32,31 sehingga dapat disimpulkan bahwa ada pengaruh model pembelajaran inkuiri terhadap perubahan sikap siswa tentang bahaya merokok.

Pelaksanaan penelitian ini dilakukan selama kurang lebih satu bulan yaitu Januari 2020 hingga. Jarak antara pelaksanaan pre-test dan post-test adalah 2 minggu. Model pembelajaran inkuiri diberikan oleh fasilitator dari dinas kesehatan Kota Kotamobagu bagian promosi kesehatan. Orang yang terpilih sebagai fasilitator adalah orang yang direkomendasikan oleh Kepala Dinas Kesehatan Kota Kotamobagu yang telah mengerti dan paham tentang promosi kesehatan. Meskipun model pembelajaran inkuiri telah banyak dikembangkan didunia pendidikan yang digunakan untuk memberikan pengalaman belajar kepada peserta didik yang lebih efektif, namun model pembelajaran inkuiri belum banyak dikembangkan dalam pendidikan kesehatan. Mengingat model pembelajaran inkuiri sangat efektif dilakukan dalam mengubah perilaku peserta didik ke arah yang lebih positif, karena model ini mencakup tiga domain perilaku yaitu kognitif (cognitive), afektif (affective), dan psikomotorik (psychomotor).

Fasilitator dan peneliti mendiskusikan model pembelajaran inkuiri yang akan diberikan kepada responden yaitu kelompok intervensi. Meliputi aspek dalam model pembelajaran inkuiri, waktu yang dibutuhkan dalam pembelajaran inkuiri, dan metode yang digunakan dalam model pembelajaran inkuiri. Metode yang digunakan dalam penelitian ini adalah ceramah (persentasi), pembelajaran aktif (diskusi dan problem solving), kartu berpasangan (matching card), dan simulasi permainan dengan bantuan media yang digunakan adalah, poster, leaflet, dan video.

Hasil uji statistik diperoleh nilai $p=0,000(p<0,05)$ dengan perbedaan rata-rata skor (mean) pengetahuan responden pada saat pre-test dan post-test sebesar 9,88 
dan diperoleh nilai $p=0,000(p<0,05)$ dengan perbedaan rata-rata skor (mean) sikap responden pada saat pre-test dan post-test sebesar 32,31 sehingga dapat disimpulkan bahwa ada pengaruh model pembelajaran inkuiri terhadap perubahan pengetahuan dan sikap siswa tentang bahaya merokok di SMAN 1 Kotamobagu.

Hasil saat pre-test ke post-test menunjukkan adanya peningkatan rata-rata skor (mean) pengetahuan responden tentang bahaya merokok sebesar 9,88 dan sikap siswa tentang bahaya rokok sebesar 32,31 setelah diberikan penyuluhan tentang bahaya merokok dengan model pembelajaran inkuiri. Model pembelajaran inkuiri membuat responden menjadi tertarik, tidak monoton dan merasa cepat bosan terhadap materi sehingga responden lebih berkonsentrasi dan mudah menyerap materi yang diberikan. Pada saat pemberian materi tercipta suasana yang memicu responden aktif dalam bertanya dan mengemukakan pendapat.

Penelitian ini sejalan dengan penelitian yang dilakukan pada mahasiswa kesehatan masyarakat Universitas Muhammadiyah Aceh yang menemukan bahwa kemampuan berpikir kritis terdapat pada model PBL dan inkuiri dengan t-hitung $>\mathrm{t}$ tabel $(3,20>2,00)$, dengan nilai pos-test $\mathrm{PBL}$ mean $=72,25$ dan mean inkuiri $=$ 81,00.(Anwar et al., 2015) Penelitian yang dilakukan di Program Pendidikan Jasmani Sekolah Dasar Turki menemukan bahwa peningkatan yang signifikan diamati di skor tes pengetahuan responden dengan nilai fleksibilitas $(z=-2.227, p<.026)$. Dengan menggunakan model Pembelajaran Berbasis Inkuiri dapat meningkatkan pengetahuan setelah dihitung pre-test dan post-test (Uzunosmanoglu et al., 2012). Penelitian yang dilakukan di SMP Negeri 6 Banda Aceh dengan jumlah sampel sebanyak 25 siswa menemukan bahwa aspek kemampuan kognitif siswa (nilai) dalam pemahaman konsep terjadi peningkatan korelasi pemahaman dan sikap siswa memiliki hubungan yang cukup. Korelasi sikap dan perilaku memiliki hubungan yang sangat kuat (Elsa et al., 2018).

Penelitian lain dengan menggunakan metode systematic riview dari database ProQuest, Google Scholar dan Science Direct dengan mengmpulkan 13 artikel dari tahun 2014-2018 dengan kata kunci "inquiry-based learning model" menemukan bahwa terdapat 10 artikel sepuluh artikel meningkatkan hasil belajar siswa sedangkan 3 lainnya tidak mempengaruhi hasil belajar siswa, tetapi dapat meningkatkan motivasi belajar siswa. Pembelajaran berbasis inkuiri melibatkan siswa secara langsung dan aktif dalam proses pembelajaran sehingga pembelajaran berpengaruh signifikan meningkatkan hasil belajar (Utami \& Sundari, 2019). Selanjutnya penelitian yang dilakukan pada ibu yang memiliki balita di Puskesmas Tempe menemukan bahwa model pembelajaran inkuiri berpengaruh terhadap respon ibu terhadap diare pada balita di Puskesmas Tempe, dengan perubahan yang signifikan pada rata-rata skor pengetahuan dan skor sikap ibu pada intervensi. dan kelompok kontrol (perbedaan masing-masing 29,26 dan 12,67). Praktik pelatihan ibu dalam penerapan terapi rehidrasi oral menghasilkan selisih 15,5 antara skor praktik rata-rata kelompok kontrol dan kelompok intervensi. Temuan ini menunjukkan bahwa model pembelajaran inkuiri lebih efektif dalam meningkatkan perilaku ibu dalam merespon diare pada balita di Puskesmas Tempe Kabupaten Wajo (Nyorong \& Burhan, 2015).

Peningkatan pengetahuan dan siswa tentang bahaya merokok setelah diberikan penyuluhan dengan model pembelajaran inkuiri karena model pembelajaran inkuiri merupakan model pembelajaran yang berupaya menanamkan dasar-dasar berfikir ilmiah pada diri peserta, sehingga dalam proses pembelajaran ini peserta lebih banyak belajar sendiri, mengembangkan kreativitas dalam memecahkan masalah dan peserta benar-benar ditempatkan sebagai subjek yang belajar. Model pembelajaran inkuiri memiliki kelebihan seperti: a) Pembelajaran ini merupakan pembelajaran yang menekankan kepada pengembangan aspek kognitif, afektif, dan psikomotor secara seimbang, sehingga pembelajaran melalui pembelajaran ini dianggap jauh lebih 
bermakna. b) Pembelajaran dapat memberikan ruang kepada siswa untuk belajar sesuai dengan gaya belajar mereka. c) Pembelajaran ini merupakan strategi yang dianggap sesuai dengan perkembangan psikologi belajar modern yang menganggap belajar adalah proses perubahan tingkah laku berkat adanya pengalaman. d) Keuntungan lain adalah dapat melayani kebutuhan siswa yanng memiliki kemampuan di atas rata-rata. Artinya, siswa yang memiliki kemampuan belajar bagus tidak akan terhambat oleh siswa yang lemah dalam belajar (Masyithah, 2017).

\section{Kesimpulan}

Berdasarkan penelitian yang telah dilakukan dapat disimpulkan bahwa ada pengaruh model pembelajaran inkuiri terhadap perubahan pengetahuan dan sikap siswa tentang bahaya merokok di SMAN 1 Kotamobagu dengan nilai $p=0,001<0,05$. Disarankan kepada Dinas Kesehatan Kotamobagu untuk mengembangkan penyuluhan kesehatan menggunakan model pembelajaran inkuiri dan seluruh petugas kesehatan Kotamobagu perlu mendapatkan pelatihan model pembelajaran inkuiri.

\section{Daftar Pustaka}

Anwar, A., Abdullah, A., \& Apriana, E. (2015). Penarapan Problem Based Learning dan Inkuiri untuk Meningkatkan Kemampuan Berpikir Kritis dan Sikap Kepedulian Lingkungan Mahasiswa Fakultas Kesehatan Masyarakat Universitas Muhammadiyah Aceh. Jurnal Edubio Tropika, 2(2).

Elsa, F., Khairil, K., \& Yunus, Y. (2018). Penerapan Pendidikan Karakter Peduli Lingkungan Melalui Metode Inkuiri Terhadap Sikap Dan Perilaku Siswa Pada Materi Pencemaran Dan Kerusakan Lingkungan Di SMP Negeri 6 Banda Aceh. BIOTIK: Jurnal IImiah Biologi Teknologi Dan Kependidikan, 2(1), 28-32.

Hutapea, C. E. Z., Rumayar, A. A., \& Maramis, F. R. R. (2017). Hubungan Antara Pengetahuan dan Sikap dengan Tindakan Terhadap Kebijakan Kawasan Tanpa Rokok Pada Siswa di SMP Kristen Tateli. KESMAS, 6(3).

Kemenkes RI. (2014). Perilaku Merokok Masyarakat Indonesia. Kementrian Kesehatan $\mathrm{RI}$.

Kemenkes RI. (2018). Hasil Utama RISKESDAS. Kementrian Kesehatan RI.

Martias, I., \& Nursamsi, S. (2017). Pengaruh Penyuluhan Mengenai Bahaya Merokok Menggunakan Media Leaflet Terhadap Perubahan Pengetahuan Dan Sikap Siswa Di SMPN 3 Bintan Timur. Jurnal Kesmas Jambi, 1(2), 76-81.

Masyithah, D. C. (2017). Pengembangan Multimedia Fisika Berbasis Model Pembelajaran Inkuiri Terbimbing dengan Menggunakan Adobe Flash CS6 pada Materi Fluida Dinamis Untuk Siswa SMA Kelas XI. Jurnal EduFisika, 2(01), 51-60.

Nugroho, R. S. (2017). PERILAKU MEROKOK REMAJA (Perilaku Merokok Sebagai Identitas Sosial Remaja Dalam Pergaulan Di Surabaya). Universitas Airlangga.

Nyorong, M., \& Burhan, H. (2015). Influence of an Inquiry-Based Learning Model on Maternal Behavior in Response to Diarrhea in Children under the Age of Five Years at the Tempe Health Center, Wajo Regency, Indonesia. Pakistan Journal of Nutrition, 14(11), 792. 
Rusmilawaty. (2016). Pengaruh Penyuluhan dengan Metode Ceramah Tentang Bahaya Rokok terhadap Perubahan Sikap Perokok Aktif. Jurnal Vokasi Kesehatan, 2(2), 113-118.

Utami, S., \& Sundari, S. (2019). Inquiry-based learning for improving student learning outcomes: literature review. Jurnal Penelitian \& Pengembangan Pendidikan Fisika, 5(1), 49-62.

Uzunosmanoglu, E., Gursel, F., \& Arslan, F. (2012). The effect of inquiry-based learning model on health-related fitness. Procedia-Social and Behavioral Sciences, 47, 1906-1910. 